\title{
Specificity and effect on apoptosis of Tat antibodies from vaccinated and SHIV-infected rhesus macaques and HIV-infected individuals
}

\author{
Guillaume Belliard ${ }^{\mathrm{a}}$, Anthony Romieu ${ }^{\mathrm{b}}$, Jean-François Zagury ${ }^{\mathrm{c}}$, Hayet Dali ${ }^{\mathrm{a}}$, \\ Olivier Chaloin ${ }^{\mathrm{a}}$, Roger Le Grand ${ }^{\mathrm{d}}$, Erwann Loret ${ }^{\mathrm{e}}$, Jean-Paul Briand ${ }^{\mathrm{a}}$, \\ Bernard Roques ${ }^{\mathrm{b}}$, Claude Desgranges ${ }^{\mathrm{f}}$, Sylviane Muller ${ }^{\mathrm{a}, *}$ \\ a UPR9021 CNRS, Institut de Biologie Moléculaire et Cellulaire, 15 rue René Descartes, 67000 Strasbourg, France \\ b Département de Pharmacochimie Moléculaire, INSERM U266-CNRS FRE 2463, Faculté de Pharmacie, Paris, France \\ c Centre de Recherches des Cordeliers, Université Pierre et Marie Curie, Paris, France \\ d Service de Neurovirologie, CEA, Fontenay-Aux-Roses, France \\ e UPR9027 CNRS, Institut de Biologie Structurale et Microbiologie, Marseille, France \\ f EMI99-32 INSERM, Institut de Génétique Moléculaire, Paris, France
}

Received 2 December 2002; received in revised form 15 March 2003; accepted 19 March 2003

\begin{abstract}
Recent contributions have demonstrated that actively secreted Tat protein plays an important functional role in human immunodeficiency virus-1 (HIV-1) infection and that Tat antibodies might interfere with disease progression by blocking the protein extracellularly. In this context we have studied the recognition of several Tat mutants as well as various synthetic Tat fragments by anti-Tat monoclonal antibodies and by IgG antibodies from a large collection of slow and fast-progressor infected individuals. We have also tested the sera from simian/human immunodeficiency virus (SHIV)-infected macaques with these Tat peptides. Important differences were found between long-term non-progressors and fast-progressors, and between human and monkey sera in terms of antibody specificity. Rabbits and macaques were immunised with several Tat peptides and we found that certain antibody subsets from immunised animals recognised the cognate protein Tat and had the capacity to inhibit Tat-induced apoptosis of T cells. Such antibodies might be important for controlling Tat-induced death in cells uninfected by HIV-1.
\end{abstract}

(C) 2003 Elsevier Science Ltd. All rights reserved.

Keywords: B cell epitopes; HIV-1; Tat protein

\section{Introduction}

The Tat protein of human immunodeficiency virus (HIV) is secreted very early after infection by HIV-infected cells and taken-up by neighbouring cells, in which Tat can reactivate latent infection or can alter the normal behaviour of non-infected cells. Tat plays a pleiotropic role on key cellular functions (cell growth and metabolism) and is therefore considered as a critical component in the mechanisms for AIDS pathogenesis. For these reasons it is regarded as a possible target for anti-HIV gene therapy and vaccine development. Tat is primarily a transactivator protein that binds in the presence of cofactors cyclin $\mathrm{T}$ and cyclin-dependent kinase 9 (CDK9), to a short leader RNA, transactivator responsive region (TAR) and has the potential to influence the initiation

\footnotetext{
${ }^{*}$ Corresponding author. Tel.: +33-388-41-70-22; fax: +33-388-61-06-80.

E-mail address: s.muller@ibmc.u-strasbg.fr (S. Muller).
}

as well as the elongation of transcription [1-4]. However, certain of its functions in cytopathogenicity are independent from its transactivation role. A wide variety of activities (for example, on angiogenesis, apoptosis, signalling) have been attributed to the extracellular Tat and it is notable that substantial levels of Tat protein $(0.1-1.0 \mathrm{ng} / \mathrm{ml}$, approximately $0.01-0.1 \mathrm{nM})$ are found in the serum of HIV-infected patients [5].

While the laboratory HIV strains produce an 86-amino acid Tat protein, most Tat proteins from primary isolates contain an additional C-terminal 15-16 residue-long sequence whose functions are not fully elucidated. Tat is encoded by two exons and is classically described as a modular protein. It contains six regions, the $\mathrm{N}$-terminus (aa 1-21 rich in prolines), the cysteine-rich region (aa 22-37), the core region (aa 38-48), the basic region (aa 49-59), the glutamine-rich region (aa 60-72), and the C-terminus encoded by the second exon and whose size varies according to the isolate (Table 1). It does show sequence variability from isolate to isolate but 
Table 1

Sequences of Tat proteins and peptides

(A)

Tat Bru (B) MEPVDPRLEPWKHPGSQPKTACTTCYCKKCCFHCQVCFTTKALGISYGRKKRRQRRRPPQGSQTHQVSLSKQPTSQPRGDPTGPKE

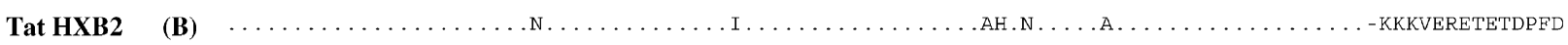

Tat CM240

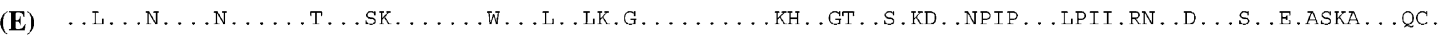

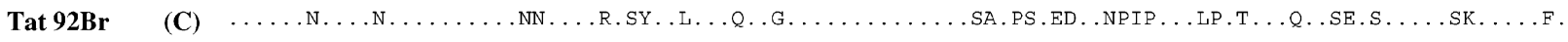

Tat Eli

(D)

Tat Ug11RP

(A) .

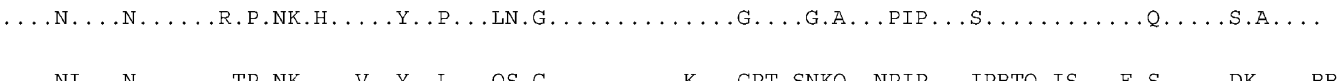

(B)

Tat 1-61

MEPVDPRLEPWKHPGSQPKTACTTCYCKKCCFHCQVCETTKALGISYGRKKRRQRRRPPQG

Tat 1-20

MEPVDPRLEPWKHPGSQPKT

Tat 8-53

LEPWKHPGSQPKTACTTCYCKKCCFHCQVCFTTKALGISYGRKKRR

Tat 19-53

KTACTTCYCKKCCFHCQVCFTTKALGISYGRKKRR

Tat 19-53m

KTACTTCYS KKCSSFHCQVISFTTKALGISYGRKKRR

Tat 44-61

GISYGRKKRRQRRRPPQG

gp41 600-612 IWGCSGKLICTTA

Measles

2 x F 288-302/ LSEIKGVIVHRLEGVLSEI KGVIVHRLEGVLDRLVRLIG

NP 51-59

contains relatively conserved residues or sequences, a conserved tryptophane residue at position 11 , seven cysteines at positions $22,25,27,30,31,34$ and 37 in the cysteine-rich region, the sequence ${ }^{43} \mathrm{LGISYG}^{48}$ in the core region, and the sequence ${ }^{49}$ RKKRRQRRRPP ${ }^{59}$ in the basic region. Using synthetic and recombinant Tat fragments as well as mutated Tat proteins, it has been possible to dissect the functions of several regions of the protein [6-12]. The N-terminal region 1-9 is involved in the binding of Tat to CD26 (DPP IV) while the region 49-57 is involved in Tat uptake. Albini et al. [8] demonstrated that the synthetic peptide 24-51 encompassing the "chemokine-like" region of Tat induces the rapid and transient $\mathrm{Ca}^{2+}$ influx in monocytes and macrophages, analogous to $\beta$-chemokines. This peptide is angiogenic in vivo [13]. Boykins et al. [9] showed that as efficiently as the entire Tat molecule, the fragment $21-41$ is sufficient to transactivate, induce HIV replication and trigger angiogenesis. Mutations at the positions 22 or 22/37 lead to a protein lacking transactivation capacities and that displays a transdominant negative phenotype [14]. Acetylation of Tat at positions $\mathrm{K}^{28}$ and $\mathrm{K}^{50}$ could be particularly important for its transactivation activity $[15,16]$. The RGD motif present in residues 78-80 is responsible for Tat-integrin binding. Several peptide analogues or molecules blocking these regions have been used with more or less success as possible blocking agents in therapeutic strategies.
Tat antibodies are detected in the serum of HIV-infected patients and number of short linear Tat epitopes recognised by IgM or IgG patients' antibodies have been characterised in several regions of the protein [17-21]. Independent groups have shown that, in contrast to antibodies to Env, Nef and Gag, the level of Tat antibodies is elevated in long-term nonor slow-progressors (SP), and is low in fast-progressors (FP), their decline in asymptomatic individuals would be related to the imminence of AIDS [21-25]. It has been reported further that the presence of Tat natural IgM antibodies present in normal individuals (and chimpanzees, but not from other primates and mice) and reacting with functional Tat regions might have some influence on the course of AIDS progression $[23,26]$. These findings obtained with rather short linear peptides may help to develop peptide-based strategies. However, attempts to "vaccinate" macaques with such short peptides (peptides 4-16 and 53-66) were disappointing [27], and until now the best protection results were obtained with the whole Tat protein and Tat toxoid [28-30].

In this study, we used long synthetic fragments encompassing several functional domains and studied their recognition by $\mathrm{IgG}$ antibodies from long-term non-progressors and fast-progressors as well as from normal blood donors. In parallel, we studied 18-20-mer peptides covering the N-terminus and the basic region of Tat, which have been demonstrated previously to contain dominant B cell 
epitopes. We also tested the sera from simian/human immunodeficiency virus (SHIV)-infected Chinese rhesus monkeys with these long fragments and shorter peptides. Important differences were found between human and monkey sera in terms of antibody specificity. Rabbits and monkeys were immunised with the Tat peptides and we found that certain antibody subsets from immunised animals recognised the cognate protein Tat and inhibited the effect of Tat that stimulates $\mathrm{T}$ cell apoptosis by the process of activation-induced cell death $[5,31]$.

\section{Materials and methods}

\subsection{Whole Tat, synthetic fragments and peptides}

Tat proteins from different HIV strains were tested in this study (Table 1). They correspond to strains Bru F12 and HBX2 (clade B, which is a major strain clade found in Europe and North America), CM240 (clade E, found in majority in Thailand), $92 \mathrm{Br}$ (clade $\mathrm{C}$, found in Brazil), Eli (clade $\mathrm{D}$, found in Zairre), and Ug11RP (clade A, found in Uganda). Tat variants were synthesised with an ABI 433A peptide synthesiser (Applied Biosystem Inc., Foster City, CA) with FASTMoc chemistry as previously described [32]. Purity (superior to 90\%) and integrity of proteins were confirmed by HPLC, amino acid composition (6300 Beckman analyser), partial sequence analyses (473A Protein Sequencer, Applied Biosystem) and by MALDI-TOF mass spectrometry (Perseptive Biosystems, Voyager DE-RP). Tat Bru was also synthesised using an improved solid-phase synthesis procedure (Chaloin and Briand, in preparation).

The long Tat fragments 1-61, 8-53 and 19-53 (Table 1) were synthesised by solid-phase method as described previously for the preparation of long peptides [33]. A mutated fragment 19-53 (called 19-53 m) containing three serine residues at positions 27, 31 and 37 instead of Cys residues was also included in the present study. The peptides 1-20 and 44-61 were synthesised using classical Fmoc ( $N$-[9-fluorenyl]metoxycarbonyl) solid-phase chemistry [34]. Their homogeneity was assessed by analytical HPLC (94 and $98 \%$ of purity, respectively) and their identity was checked by matrix-assisted laser desorption and ionisation time-of-flight mass spectrometry using a protein $\mathrm{TOF}^{\mathrm{TM}}$ apparatus (Brucker Spectrospin, Bremen, Germany). The sequence of all Tat peptides corresponds to the cognate Tat protein Bru (Table 1). The synthesis, purification and characterisation of the cyclic peptide $600-612$ of HIV-1 gp41 and measles chimeric peptide $2 \times$ F288-302/NP51-59 (Table 1) were described previously $[35,36]$.

\subsection{Sera}

A total of 163 sera from HIV-infected individuals were studied. They were collected in France from fast-progressor and slow-progressor individuals recruited in various hospi- tal centres in Paris and surrounding provinces in the context of the Génétique de la Résistance à l'Infection au VIH-1 (GRIV) program $[25,37,38]$. In the present study we did not differentiate stable non-progressors from SP patients who progressed subsequently [25]. Sera, identified by a code number, were heated at $56^{\circ} \mathrm{C}$ for $30 \mathrm{~min}$, centrifuged, divided into aliquots, and stored at $-20^{\circ} \mathrm{C}$ until tested. In addition, the sera from 45 normal blood donors were included in the enzyme linked immunosorbent assay (ELISA) test as control.

Anti-Tat mouse monoclonal antibodies TA9, TB12, TC15, TD84 and TE135 were a kind gift from Dr. J.-L. Guesdon, Institut Pasteur, Paris. Rabbit antisera were raised by a series of four to five subcutaneous (s.c.) injections of $100 \mu \mathrm{g}$ of unconjugated peptides emulsified in complete Freund's adjuvant (CFA) at intervals of 2 weeks. Antiserum was collected at regular intervals over a period of 2 months. To boost the antibody response against the peptides 1-20 and 44-61 of Tat, four rabbits (Cla and Aug, and Cam and Lan) received the peptides mixed with $2 \mathrm{mg}$ methylated BSA and emulsified in CFA for the first and subsequent injections.

Nineteen male rhesus macaques (Macaca mulatta; origin China; weight at the start of experiments; $3.5-9.5 \mathrm{~kg}$ ) were housed at the Centre de Primatologie of Niederhausbergen (Strasbourg Louis Pasteur University). They were negative for Salmonella, Shigella, Campylobacter, Ectoparasitis and Herpes B virus, and were regularly treated with tuberculin. All animal care and use procedures conformed to the European regulation on use of laboratory non-human primate animals. Animals were tranquillised with $10 \mathrm{mg} / \mathrm{kg}$ ketamine hydrochloride intramuscularly prior to all procedures. Four groups of monkeys (A-D, Table 2) were immunised with Tat peptides, a fifth control group of monkeys (E) received adjuvant only at each administration. Three monkeys (group A) were immunised intra-muscularly (i.m.) and intra-nasally (i.n.) with the Tat peptide $8-53(50 \mu \mathrm{g}$ in $1 \mathrm{ml}$ phosphate-buffered saline (PBS)/injection/monkey) and the adjuvant aluminum phosphate (alum; $1: 1 \mathrm{v} / \mathrm{v}$ ) for the first four injections and the adjuvant Montanide ISA 720 (Seppic, Paris, France; 1:3 v/v) for the subsequent injections (Table 2). Three monkeys of the group $\mathrm{B}$ received the same 8-53 peptide i.m. and i.n. mixed with CpG 2006 (Eurogentec, Seraing, Belgium) and alum for the three first injections and Montanide ISA 720 for the subsequent ones (Table 2). The procedure of immunisation of the group $\mathrm{C}$ (three monkeys) was identical to the one applied in group B, except that the immunogen was a mixture containing 1-20, 8-53, 19-53 and 19-53m Tat peptides. The group D (seven monkeys) received a mixture of 1-20, 1-61 and 44-61 Tat peptides in the presence of Montanide ISA 720 at each injection. No sign of local or systemic toxicity were seen at the time of vaccination. Monkeys were bled 1 month after each administration.

The sera from three rhesus macaques (PS1, PS2 and PS10) infected with the chimeric SHIV BX08 strain were also 
Table 2

Monkeys and vaccination protocols

\begin{tabular}{|c|c|c|c|c|}
\hline Group & Monkeys & Immunogen & Adjuvant and timing & \\
\hline A & $\begin{array}{l}0140 \\
0178 \\
0181\end{array}$ & $8-53(50 \mu \mathrm{g} / \mathrm{ml})$ & $\begin{array}{l}\text { Alum } \\
\text { Montanide ISA } 720\end{array}$ & $\begin{array}{l}\text { Injections } 1-4 \text { (days } 0,30,60,97) \\
\text { Injections } 5 \text { and } 6 \text { (days } 127,246)\end{array}$ \\
\hline B & $\begin{array}{l}0183 \\
0201 \\
0205\end{array}$ & $8-53(50 \mu \mathrm{g} / \mathrm{ml})$ & $\begin{array}{l}\text { CpG } 2006 \text { + Alum } \\
\text { CpG } 2006 \text { + Montanide ISA } 720\end{array}$ & $\begin{array}{l}\text { Injections } 1-3 \text { (days } 0,30,60 \text { ) } \\
\text { Injections } 4-6 \text { (days 97, 127, 246) }\end{array}$ \\
\hline $\mathrm{C}$ & $\begin{array}{l}0287 \\
0299 \\
0301\end{array}$ & $1-20,8-53,19-53,19-53 \mathrm{~m}(50 \mu \mathrm{g} / \mathrm{ml}$ each $)$ & Idem group B & \\
\hline $\mathrm{D}$ & $\begin{array}{l}1071 \\
1072 \\
1086 \\
1088 \\
1092 \\
1096 \\
1098\end{array}$ & $1-20,1-61,44-61(50 \mu \mathrm{g} / \mathrm{ml}$ each $)$ & Montanide ISA 720 & Injections $1-5$ (days $0,33,68,104,134$ ) \\
\hline $\mathrm{E}$ & $\begin{array}{l}1061 \\
1063 \\
1069\end{array}$ & PBS & Idem group D & \\
\hline
\end{tabular}

Macaques of groups A-D were immunised i.m. and i.n. with Tat peptides diluted in PBS containing alum or Montanide ISA 720 as described in Section 2. Monkeys of groups B and C received Tat peptides mixed with CpG 2006 (150 $\mu \mathrm{g} / \mathrm{injection/monkey).} \mathrm{Monkeys} \mathrm{of} \mathrm{group} \mathrm{E} \mathrm{received} \mathrm{Montanide} \mathrm{only.}$

introduced in this study [39]. The Tat sequence in SHIV BX08 corresponds to that of HIV Lai Tat.

\subsection{Enzyme linked immunosorbent assay (ELISA)}

Polyvinyl (Falcon, Oxnard, CA) or MaxiSorp ${ }^{\mathrm{TM}}$ (Nunc, Roskilde, Denmark) microtitre plates were coated overnight at $4{ }^{\circ} \mathrm{C}$ with the Tat proteins and peptides diluted in $0.05 \mathrm{M}$ carbonate buffer, $\mathrm{pH}$ 9.6. The test conditions were calibrated for each protein and peptide in terms of solid-phase support and antigen concentrations, which were found to highly depend on the type and origin of antibody tested (see the conditions in the respective tables showing the data). In each assay, sera were also tested in a non-coated well incubated with coating buffer as a control. The subsequent steps of the test were performed, as described previously [40], using sera diluted in PBS containing $0.05 \%(\mathrm{v} / \mathrm{v})$ Tween (PBS-T) and $0.3 \%(\mathrm{w} / \mathrm{v}) \mathrm{BSA}$, and horseradish peroxidase-conjugated second antibodies diluted in PBS-T. Second antibodies were from Jackson ImmunoResearch Laboratories (West Groves, PA) for human IgG (working dilution $1 / 45,000$ ), and total Ig $(1 / 30,000)$, for mouse IgG (dilution $1 / 20,000$ ), as well as for rabbit $\operatorname{IgG}$ (dilution 1/30,000), and from Rockland (Gilbertville, PA) for monkey IgG (dilution $1 / 65,000$ ). The final reaction was detected using 3,3',5,5'-tetramethyl benzidine in the presence of $\mathrm{H}_{2} \mathrm{O}_{2}$.

The cut-off points of each assay were determined with the sera from non-immunised rabbits and mice or from normal individuals. Test sera were considered positive when the OD values were higher than the mean OD +2 S.D. In the case of monkey antisera, the bleeds of 19 monkeys taken prior to immunisation were used to calculate the limit of positivity. Cut-off values calculated from the OD values measured with each peptide were $<0.2$. Monkey antisera showing an OD value superior to 0.2 in duplicate tests were thus considered positive. In the wells without antigen, ODs measured with monkey antisera were always $<0.2$.

Competitive ELISA assays using the Tat protein in solution were also performed in which increasing amounts of Tat were first incubated with constant dilutions of antisera for $1 \mathrm{~h}$ at $37^{\circ} \mathrm{C}$. The mixtures were then added to wells pre-coated with Tat or Tat fragment 8-53 and the test performed as for the direct ELISA.

\subsection{Apoptosis}

The effect of Tat Bru and of the different Tat peptides and of anti-Tat antibodies was tested on Jurkat $\mathrm{T}$ cells incubated with anti-CD3 antibodies to induce apoptosis. Supernatant containing anti-CD3 antibody OKT3 secreting hybridomas was affinity-purified by chromatography on protein G. Jurkat cells were cultivated in RPMI 1640 supplemented with $10 \%(\mathrm{v} / \mathrm{v})$ foetal calf serum (FCS), and $10 \mu \mathrm{g} / \mathrm{ml}$ gentamycin. For the test, 96-well-flat bottomed plates were coated with $0.5-1 \mu \mathrm{g} / \mathrm{ml}$ OKT3 antibody diluted in sterile PBS and incubated for $1 \mathrm{~h}$ at $37^{\circ} \mathrm{C}$, and then for $24 \mathrm{~h}$ at $4{ }^{\circ} \mathrm{C}$. The plates were then saturated with culture medium for $1 \mathrm{~h}$ at $37^{\circ} \mathrm{C}$. Jurkat $\mathrm{T}$ cells $(200 \mu \mathrm{l} /$ well at a final concentration of $2 \times 10^{5}$ cells $/ \mathrm{ml}$ ) were then incubated at $37^{\circ} \mathrm{C}$ with $1 \mu \mathrm{M}$ Tat protein or Tat peptides in the presence or not of decomplemented rabbit or monkey antisera (final $28 \mu \mathrm{l}$ serum in $200 \mu \mathrm{l}$ medium). Rabbit antibodies to peptide 44-61 were 
also tested after affinity purification on a $\mathrm{CNBr}$-activated sepharose 4B column (Amersham Biosciences Europe, Freiburg, Germany) activated with the peptide. After $20 \mathrm{~h}$ incubation, Jurkat cells were harvested, stained with propidium iodide and annexin V, and analysed by flow cytometry using a FACSCalibur instrument (Becton Dickinson, Mountain View, CA). The percentage of specific apoptosis in the presence or absence of antibodies was calculated as follows: $100 \times$ (experimental percentage of annexin $\mathrm{V}$ positive cells - spontaneous percentage of annexin $\mathrm{V}$ positive cells $) /(100$ - spontaneous percentage of annexin $\mathrm{V}$ positive cells).

\subsection{Statistical analysis}

Statistical analysis was performed using the two-tailed Student's $t$-test. $P$ inferior or equal to 0.05 was considered to be statistically significant.

\section{Results}

\subsection{Reactivity in ELISA of sera from HIV-infected individuals with Tat proteins and related peptides}

In a first series of experiments, the serum from 20 HIV-seropositive individuals (six fast-progressors, eight slow-progressors and six unclassified) were tested in ELISA for their reactivity with Tat proteins as well as with the Tat related and control peptides described in Table 1. Following optimisation of the test conditions, the Tat proteins $(0.2 \mu \mathrm{M})$ as well as Tat peptides 1-20, 1-61 and 44-61 were tested after coating onto Maxisorp ${ }^{\mathrm{TM}}$ polystyrene microtitre plates, while the other peptides (Tat 8-53, Tat 19-53, Tat 19-53m, gp41 600-612) were tested after coating onto polyvinyl Falcon plates. The optimal concentration of all peptides used for coating plates was $0.2 \mu \mathrm{M}$ except for peptides $1-20$ and $44-61(2 \mu \mathrm{M})$. The cut-off values were calculated from the OD values measured with each Tat protein and peptide and the serum of 20 healthy blood donors evaluated with anti-IgG or anti-total Ig second antibody (Table 3). When these threshold values were used, none of the sera from normal individuals was found positive. As shown in Table 3 and Fig. 1, Tat proteins from distinct HIV strains of clades B, A and D were recognised equally well by patients' antibodies both in terms of frequency (almost all sera tested reacted with the four proteins) and mean OD values of positivity. In contrast, Tat proteins of clades $\mathrm{C}$ and E (Tat 92Br and Tat CM240) were not recognised at all by patients' antibodies. This result is in good agreement with the fact that the sera tested were from infected individuals from Europe and western/central Africa.

The reactivity of patients' sera was then tested with overlapping Tat peptides (sequence of the Bru strain) as well as with the negative control chimeric measles peptide (which

Table 3

Reactivity in ELISA of sera from $20 \mathrm{HIV}$-infected individuals with Tat proteins and peptides

\begin{tabular}{|c|c|c|c|c|c|}
\hline \multirow[t]{2}{*}{ Antigen } & \multirow{2}{*}{$\begin{array}{l}\text { Concentration in } \\
\text { ELISA test }(\mu \mathrm{M})\end{array}$} & \multicolumn{2}{|c|}{ Percentage of positive sera ${ }^{a}$} & \multicolumn{2}{|c|}{ Mean OD \pm S.D. of sera ${ }^{b}$} \\
\hline & & $\operatorname{IgG}$ & Total Ig & $\mathrm{IgG}$ & Total Ig \\
\hline Tat Bru & 0.2 & 100 & 100 & $1.05 \pm 0.20$ & $0.89 \pm 0.20$ \\
\hline Tat HXB2 & 0.2 & 95 & 100 & $0.46 \pm 0.19$ & $0.46 \pm 0.19$ \\
\hline Tat CM240 & 0.2 & 0 & 0 & $0.07 \pm 0.02$ & $0.07 \pm 0.03$ \\
\hline Tat $92 \mathrm{Br}$ & 0.2 & 0 & 0 & $0.03 \pm 0.02$ & $0.02 \pm 0.01$ \\
\hline Tat Eli & 0.2 & 100 & 100 & $0.65 \pm 0.19$ & $0.58 \pm 0.21$ \\
\hline Tat Ug11RP & 0.2 & 100 & 100 & $1.09 \pm 0.22$ & $0.98 \pm 0.22$ \\
\hline Tat $1-20$ & 2 & 0 & 0 & $0.05 \pm 0.03$ & $0.04 \pm 0.02$ \\
\hline Tat $1-61$ & 0.2 & 100 & 100 & $1.63 \pm 0.23$ & $1.48 \pm 0.24$ \\
\hline Tat $8-53$ & 0.2 & 100 & 100 & $2.00 \pm 0.39$ & $1.83 \pm 0.40$ \\
\hline Tat $19-53$ & 0.2 & 95 & 90 & $0.67 \pm 0.31$ & $0.58 \pm 0.28$ \\
\hline Tat $19-53 \mathrm{~m}$ & 0.2 & 100 & 100 & $1.51 \pm 0.32$ & $1.32 \pm 0.29$ \\
\hline Tat $44-61$ & 2 & 100 & 100 & $1.51 \pm 0.22$ & $1.37 \pm 0.19$ \\
\hline gp41 600-612 & 0.2 & 95 & 90 & $1.46 \pm 0.75$ & $1.09 \pm 0.59$ \\
\hline \multirow[t]{2}{*}{ Measles peptide } & $0.2^{1}$ & 0 & 0 & $0.01 \pm 0.01$ & $0.04 \pm 0.03$ \\
\hline & $0.2^{2}$ & 0 & 0 & $0.04 \pm 0.02$ & $0.02 \pm 0.01$ \\
\hline
\end{tabular}

${ }^{a}$ For the calculation of the frequency $(\%)$, sera diluted $1 / 1000$ were considered positive when the OD values measured at 450 nm were greater than the mean OD obtained for 20 normal human sera tested in parallel +2 S.D. The cut-off values have been calculated from the OD values measured with each Tat protein and peptide and the serum of healthy donors evaluated with anti-IgG or anti-total Ig second antibody. They correspond to Tat protein Bru (IgG: 0.033, total Ig: 0.030), Tat 1-20 (IgG: 0.054, total Ig: 0.034), Tat 1-61 (IgG: 0.038, total Ig: 0.031), Tat 8-53 (IgG: 0.134, total Ig: 0.098), Tat 19-53 (IgG: 0.065, total Ig: 0.039), Tat 19-53m (IgG: 0.093, total Ig: 0.039), Tat 44-61 (IgG: 0.159, total Ig: 0.183), gp41 600-612 (IgG: 0.053, total Ig: 0.023), measles peptide coated onto polyvinyl Falcon plates ${ }^{1}$ (IgG: 0.032 , total Ig: 0.093 ) or onto Maxisorp ${ }^{\mathrm{TM}}$ plates $^{2}$ (IgG: 0.025 , total Ig: 0.017). For screening assay, a threshold OD value corresponding to 0.2 was used as a cut-off. The Tat proteins as well as Tat peptides $1-20$, $1-61$, and 44-61 were tested after coating onto Maxisorp ${ }^{\mathrm{TM}}$ microtitre plates, while the other peptides, namely, Tat 8-53, Tat 19-53, Tat 19-53m, gp41 600-612 were tested after coating onto polyvinyl Falcon plates.

${ }^{\mathrm{b}}$ Mean OD values measured at $450 \mathrm{~nm}+$ S.D. calculated for all sera. 


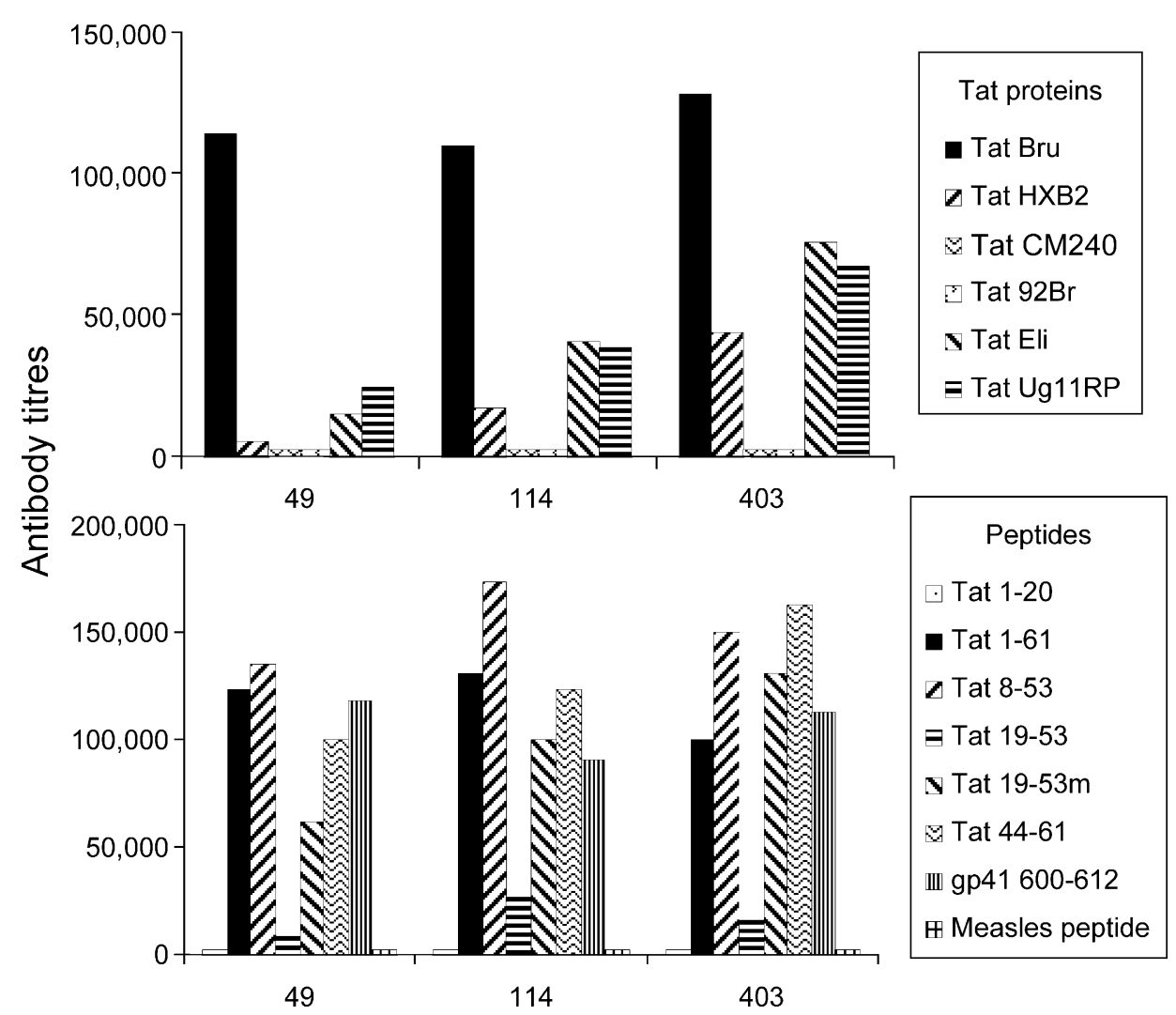

Fig. 1. IgG antibody titres of sera from three representative infected individuals $(49,114,403)$ measured in ELISA with Tat proteins and peptides. The titres correspond to the reciprocal dilution giving an absorbance of 0.2 at $450 \mathrm{~nm}$ in the test conditions described in Table 3 .

contains a T cell epitope of the virus but no B cell epitope) and the positive control peptide $600-612$ of gp41. No reactivity was found with the control measles peptide. However, as expected, the cyclic gp41 peptide 600-612 was recognised by most of the sera (Table 3 ). This peptide present in the sequence 598-609 in the gp41 ectodomain contains an important immunodominant B cell epitope, which has been shown to be important for the differential diagnosis of infections caused by HIV-1 and HIV-2 and is used in routine tests for diagnosis of HIV-infected individuals [41-43]. The sera of HIV-1 infected patients reacted strongly with Tat peptides $1-61,8-53$ and 44-61, and frequently but somewhat more weakly with fragment 19-53 (Table 3; Fig. 1). Their reactivity was not affected by the replacement of $\mathrm{Cys}^{27,31,37}$ by Ser residues at these positions in the peptide $19-53 \mathrm{~m}$. No reaction, however, was detectable in our ELISA format with the Tat peptide 1-20. Antibody levels measured with anti-IgG and anti-total Ig second antibodies were very similar (Table 3). Although our ELISA results are only semi-quantitative, this might indicate that the anti-Tat antibody response measured in the serum of HIV-1-infected patients was mainly represented by $\operatorname{IgG}$ antibodies.

To assess the relative reactivity of patients' sera according to the progression of the disease, we tested a large collection of sera from $101 \mathrm{SP}$ and $42 \mathrm{FP}$ infected individuals (Fig. 2; systematic testing at a single serum dilution). No distinction could be observed between the level of reactivity of sera from SP and FP individuals with Tat fragments 8-53, 19-53 and $19-53 \mathrm{~m}(P>0.7)$. However, the sera from FP patients reacted preferentially with peptides $1-61(P<0.0001)$ and 44-61 $(P=0.0172)$, and compared to the sera from FP patients, those from SP patients reacted preferentially with the gp41 peptide $600-612(P<0.0001)$.

\subsection{Reactivity in ELISA of anti-Tat monoclonal antibodies with Tat proteins and peptides}

Five monoclonal antibodies of $\mathrm{IgG}$ isotype generated from mice immunised with the whole Tat protein (strain Lai/Bru) were tested with Tat proteins and peptides (Fig. 3). The ELISA test with Tat proteins from different strains showed that monoclonal antibodies TA9, TD84 and TE135 recognise Tat proteins of clade B only (Bru and HXB2) and not Tat proteins of clades A, C, D and E (Tat Ug11RP, Eli, CM240 and Tat 92Br). TB12 and TC15 antibodies recognised Tat proteins of clade B, TC15 reacted also with Tat protein Eli (clade D) but not with Tat proteins of clades A, C and E.

The antibody TC15 was negative with all Tat peptides tested (Bru sequences) suggesting that it reacts with a conformational epitope not represented in the large and short fragments tested. In contrast, the other four monoclonal antibodies reacted with several Tat peptides (Fig. 3). TA9, TB12, 

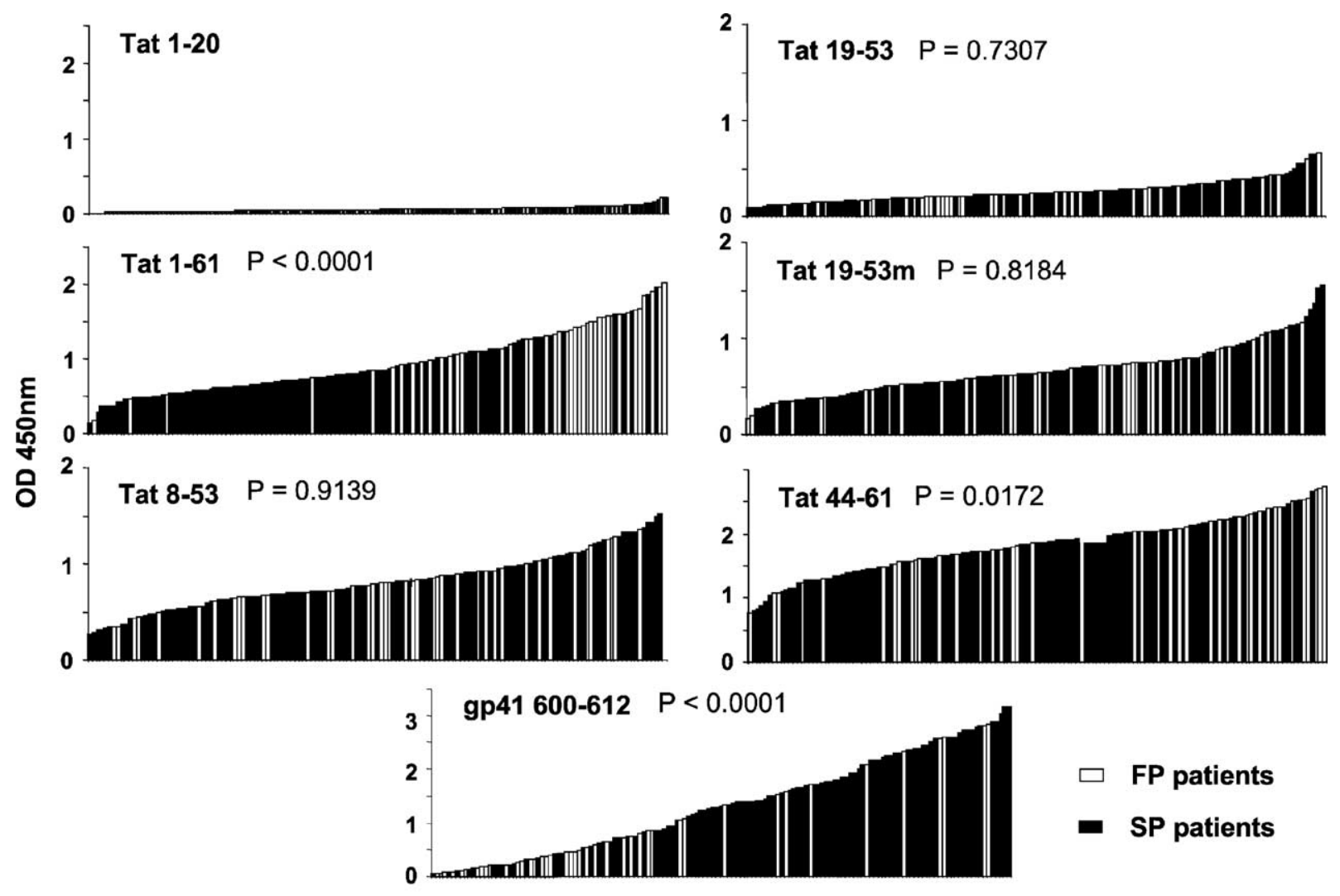

Patient's sera

Fig. 2. Reactivity in ELISA of 143 sera from fast-progressor $(\square)$ and slow-progressor $(\square)$ infected individuals with Tat peptides. The test conditions were those described in the legend of Table 3 except for peptide 1-61 that was coated onto polyvinyl plates (Maxisorp ${ }^{\mathrm{TM}}$ plates in Table 3). The sera were diluted 1/1000, and the second antibody at a 1/35,000 dilution. The reactivity of IgG antibodies only is shown, that of antibodies detected with an anti-total Ig second antibody was very similar, both in term of frequency and intensity of the ELISA reaction. The results are represented according to the intensity of OD values measured in ELISA at $450 \mathrm{~nm}$. Depending of the antigens tested, the cut-off values measured with the anti-IgG second antibody and the sera from 38 normal human sera were comprised between 0.125 and 0.226 . Arbitrarily, the cut-off value used for calculation was established at 0.200 OD unit. When this threshold value was used, none of the sera from healthy blood donors was found positive. The OD values measured with the sera and the measles peptide used as control were less than cut-off value. The $P$-values comparing the results obtained with fast and slow-progressors were generated using the Student's $t$-test and all OD values obtained with positive and negative sera.

TD84 and TE135 reacted strongly with the large fragment 1-61 and all but TB12 reacted with the peptide 1-20. TA9 also reacted with the fragment $8-53$ but none of antibodies reacted with the fragments $19-53$ or $19-53 \mathrm{~m}$. Among the five monoclonal antibodies tested, TB12 was the only one to react with the Tat peptide 44-61. From these results it can be concluded that TA9, TD84 and TE135 recognise at least one epitope in the N-terminal region of the protein, while the antibody TB12 recognises at least one epitope in the basic region 44-61.

\subsection{Reactivity in ELISA of antibodies from rabbits immunised with Tat peptides}

Twelve rabbits were immunised with Tat peptides 1-20 $(n=4), 8-53(n=2), 19-53(n=2), 19-53 \mathrm{~m}(n=2)$ and 44-61 $(n=2)$. They were injected in the presence of CFA with unconjugated peptides except two rabbits that were im- munised with peptide 1-20 and two rabbits that were immunised with peptide 44-61 co-injected with methylated BSA. Table 4 shows the results obtained with the only rabbits that mounted an antibody response against the immunising peptide. As expected, antibodies raised against each peptide reacted with the immunising as well as with peptides containing the totality or a part of the immunising sequence. In addition, several observations can be pointed out (Table 4). First, there is a complete cross-reactivity between antibodies to peptides $19-53$ and $19-53 \mathrm{~m}$ (rabbits Bil, Lus, Mal), indicating that the mutation $\mathrm{C} \rightarrow \mathrm{S}$ in positions 27,31 and 37 did not significantly affect the reactivity of both peptides. Second, antibodies raised in both rabbits Kaz and Sam against peptide 8-53 did not cross-react with peptides 19-53 and $19-53 \mathrm{~m}$ suggesting either that antibodies raised against peptide 8-53 react preferentially with the $\mathrm{N}$-terminal part of the fragment or that there is a structural change between the fragment $8-53$ and $19-53$ that affects antibody binding. It is 


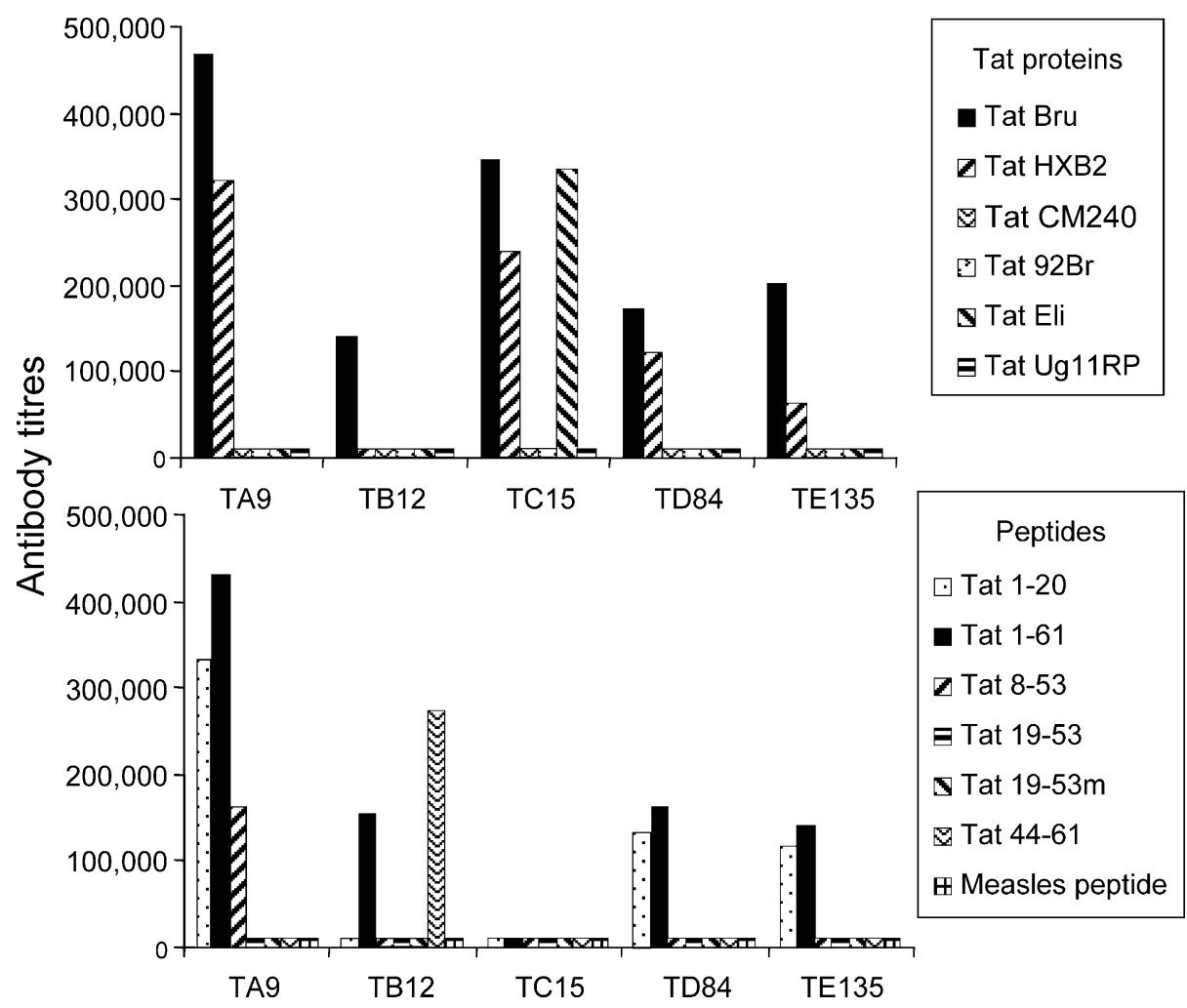

Fig. 3. Titres of mouse monoclonal antibodies to Tat measured in ELISA with Tat proteins and peptides. The titres correspond to the reciprocal dilution giving an absorbance of 0.2 at $450 \mathrm{~nm}$ in the test conditions described in the text.

notable to this regard that antibodies to peptides 19-53 and $19-53 \mathrm{~m}$ react equally well with the immunising peptides and the fragment 8-53. Third, and of importance, antibodies to peptides 1-20 (weakly), 8-53 and 19-53, but not antibodies to peptides $19-53 \mathrm{~m}$ and $44-61$ react with the whole Tat protein. The same picture is observed with the reactivity of these antisera with the fragment 1-61, with the exception of antibodies from rabbit Lan immunised with peptide 44-61 that react with the fragment 1-61 but not with the whole Tat molecule (Table 4).

\subsection{Reactivity in ELISA of antibodies from macaques immunised with Tat peptides}

Nineteen macaques distributed in five groups were included in this study. Both the number of monkeys per group

Table 4

Reactivity in ELISA of antisera from rabbits immunised with Tat peptides

\begin{tabular}{|c|c|c|c|c|c|c|c|c|c|c|}
\hline \multirow[t]{2}{*}{ Antigen } & \multirow{2}{*}{$\begin{array}{l}\text { Concentration in } \\
\text { ELISA test }(\mu \mathrm{M})\end{array}$} & \multicolumn{2}{|c|}{ Anti-peptide 1-20 } & \multicolumn{2}{|c|}{ Anti-peptide $8-53$} & \multirow{2}{*}{$\begin{array}{l}\text { Anti-peptide 19-53 } \\
\text { Bil }\end{array}$} & \multicolumn{2}{|c|}{ Anti-peptide $19-53 \mathrm{~m}$} & \multicolumn{2}{|c|}{ Anti-peptide $44-61$} \\
\hline & & Can & Mac & $\mathrm{Kaz}$ & Sam & & Lus & Mal & Cam & Lan \\
\hline Tat $1-20$ & 2 & 800 & 1900 & 14000 & 1600 & - & - & - & - & - \\
\hline Tat $8-53$ & 0.05 & - & - & 82000 & 21000 & 26000 & 23000 & 10000 & - & - \\
\hline Tat $19-53$ & 0.05 & - & - & - & - & 14000 & 10000 & 4000 & - & - \\
\hline Tat $19-53 \mathrm{~m}$ & 0.05 & - & - & - & - & 9000 & 16000 & 5000 & - & - \\
\hline Tat $44-61$ & 0.25 & - & - & - & - & - & 1500 & - & 10000 & 36000 \\
\hline Tat & 0.1 & - & 900 & 33000 & 6000 & 5000 & - & - & - & - \\
\hline Tat $1-61$ & 0.1 & - & 800 & 34000 & 26000 & 2500 & - & - & - & 3000 \\
\hline
\end{tabular}

Rabbits were immunised s.c. in the presence of CFA as adjuvant with unconjugated Tat peptides except in the case of rabbits Cam and Lan that received the peptide 44-61 mixed with methylated BSA. The reactivity of bleedings was evaluated by ELISA using the whole Tat protein Bru and the Tat peptides as antigens for coating plates. IgG antibodies only were tested and the data described here correspond to the test of the bleeding collected $1 \mathrm{week}$ after the last injection. The rabbits Can, Mac, Cam and Lan received five injections and rabbits Kaz, Sam, Bil, Lus and Mal four injections. The bleeds collected from each rabbit before immunisation were used to determine the cut-off OD value for positivity of the respective assays. The data are expressed as antibody titres corresponding to the reciprocal dilution giving an OD value equal to 0.2 . The sign $(-)$ stands for titres $<500$. As a control, antisera were tested with the measles peptide coated onto polyvinyl Falcon plates at $0.05 \mu \mathrm{M}$ and onto Maxisorp ${ }^{\mathrm{TM}}$ plates at $0.1 \mu \mathrm{M}$ and were negative (titres $<500$ ). 
and the immunising protocol are described in Table 2. Groups A-D were immunised with Tat peptides in the presence of adjuvant, the group $\mathrm{E}$ was a control group that received adjuvant only. Groups $\mathrm{A}$ and $\mathrm{B}$ received the Tat peptide 8-53 alone while macaques of groups $\mathrm{C}$ and $\mathrm{D}$ received a cocktail of Tat peptides. The antibody response in each macaque was first tested in an indirect ELISA format after optimisation of the test (Table 5). Several observations can be pointed out: (i) as expected the sera from macaques of group $\mathrm{E}$ were negative with Tat and all Tat peptides tested; (ii) in the series of macaques immunised with Tat peptides (groups A-D), only one in the group D (No. 1088) developed no response at all to the immunising peptides and overlapping peptides. In the same group, macaques 1072 and 1086 mounted a very weak IgG antibody response. In contrast, the other macaques developed a good antibody response, which was mainly directed against peptide 8-53 in groups A-C (immunised with this peptide alone or present in the cocktail), but also in the group D that received the mixture of peptide $1-20,1-61$ and 44-61. Overall 13 of 16 macaques immunised with Tat peptides produced high titres of antibodies reacting with peptide 8-53 (titres 3000-30,000). In most cases, these antibodies cross-reacted weakly in ELISA with peptides 1-20, 1-61, 19-53 and 19-53m; (iii) with the exception of macaque 1096, all macaques developed a very weak or no antibody response to peptide 44-61; (iv) of the 16 macaques immunised with Tat peptides, six produced IgG antibodies cross-reacting with the whole Tat protein with antibody titres higher than 1000 . They are two macaques in each of groups A (2/3), C (2/3) and D (2/7; Table 5).

The reactivity of macaques' antibodies with Tat was also tested in a competitive ELISA format using increasing amounts of the protein in solution. ELISA plates were coated with either Tat itself (Fig. 4a) or with Tat fragment 8-53 (Fig. 4b). As shown in Fig. 4a, antibodies from all macaques tested reacted in ELISA with Tat present in the fluid phase. There was no direct relationship between

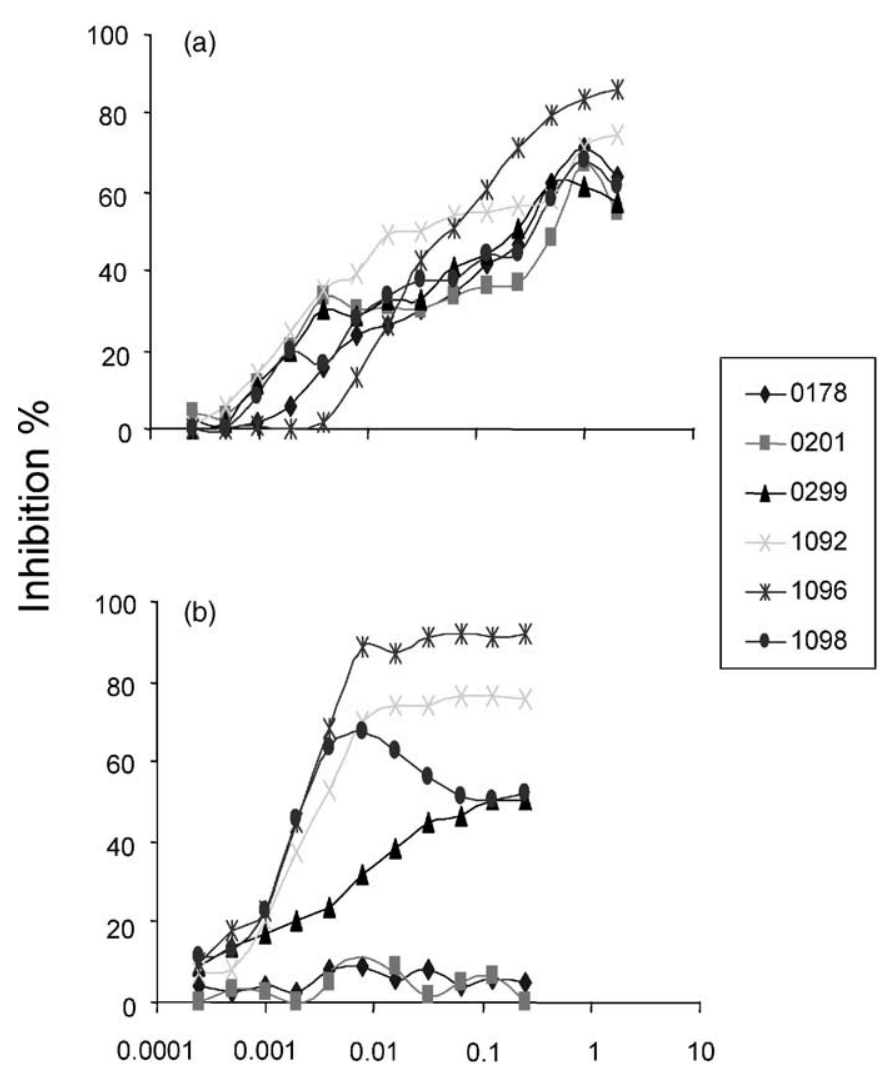

\begin{tabular}{c|c|c} 
& $\begin{array}{c}\text { Titer } \\
\text { (Direct ELISA) }\end{array}$ & IC50 $(\mu \mathrm{M})$ \\
\hline 0178 & 1,500 & 0.31 \\
0201 & 500 & 0.54 \\
0299 & 5,000 & 0.24 \\
1092 & 400 & 0.03 \\
1096 & 3,000 & 0.06 \\
1098 & 2,000 & 0.36
\end{tabular}

\begin{tabular}{c|c|c} 
& $\begin{array}{c}\text { Titer } \\
\text { (Direct ELISA) }\end{array}$ & IC50 $(\mu \mathrm{M})$ \\
\hline 0178 & 27,000 & $>>2$ \\
0201 & 13,000 & $>>2$ \\
0299 & 30,000 & 0.12 \\
1092 & 4,000 & 0.004 \\
1096 & 5,000 & 0.003 \\
1098 & 4,000 & 0.003
\end{tabular}

\section{Tat concentration $(\mu \mathrm{M})$}

Fig. 4. Inhibition of the ELISA reaction between anti-peptide antibodies from macaques and Tat or Tat fragment 8-53 by increasing concentrations of Tat. The reactivity of antisera from six macaques with the whole Tat protein Bru in solution was tested using a competitive ELISA in which Tat or Tat fragment 8-53 was used for coating plates and soluble Tat as competitor. IgG antibodies only were tested. Inhibition is expressed in percentage. The dilution of each antiserum was chosen to give an OD value close to 1.0 (final serum dilution 1/100 to 1/1600). For each antiserum, the titre obtained in the direct ELISA (Table 5) and the IC50 value measured in the ELISA competitive test are shown in the figure. The IC50 value corresponds to the amount of soluble Tat protein required to inhibit $50 \%$ of the antibody binding. No inhibition was observed when the measles peptide was tested as competitor. Coated antigen: (a) Tat $0.1 \mu \mathrm{M}$ and (b) Tat 8-53 0.05 $\mu \mathrm{M}$. 
Table 5

Reactivity in ELISA of antisera from macaques immunised with Tat peptides

\begin{tabular}{|c|c|c|c|c|c|c|c|c|c|c|c|c|c|c|c|c|c|c|c|c|}
\hline \multirow[t]{2}{*}{ Antigen } & \multirow[t]{2}{*}{$\begin{array}{l}\text { Concentration in } \\
\text { ELISA test }(\mu \mathrm{M})\end{array}$} & \multicolumn{3}{|c|}{ Group A $8-53$} & \multicolumn{3}{|c|}{ Group B 8-53 } & \multicolumn{3}{|c|}{$\begin{array}{l}\text { Group C } 1-20+8-53 \\
+19-53+19-53 \mathrm{~m}\end{array}$} & \multicolumn{7}{|c|}{ Group D 1-20 + 1-61 + 44-61 } & \multicolumn{3}{|c|}{ Group E PBS } \\
\hline & & 0140 & 0178 & 0181 & 0183 & 0201 & 0205 & 0287 & 0299 & 0301 & 1071 & 1072 & 1086 & 1088 & 1092 & 1096 & 1098 & 1061 & 1063 & 1069 \\
\hline Tat Bru & 0.1 & 300 & 1500 & 2000 & 300 & 500 & 400 & 400 & 5000 & 11000 & 900 & 300 & 600 & - & 400 & 3000 & 2000 & - & - & - \\
\hline Tat $1-20$ & 2 & - & 600 & 200 & 200 & 200 & - & 200 & 2000 & 2000 & 800 & 200 & 100 & - & 400 & 700 & 2000 & - & - & - \\
\hline Tat $1-61$ & 0.1 & 100 & 2000 & 800 & 800 & 600 & 200 & 300 & 5000 & 6000 & 700 & 200 & 200 & - & 600 & 5000 & 2000 & - & - & - \\
\hline Tat $8-53$ & 0.05 & 4500 & 27000 & 21000 & 7000 & 13000 & 4000 & 3000 & 30000 & 22000 & 3000 & 300 & 100 & - & 4000 & 5000 & 4000 & - & - & - \\
\hline Tat $19-53$ & 0.05 & 100 & 300 & 2000 & 300 & 200 & 200 & 100 & 4000 & 3000 & 200 & 200 & - & - & - & - & 200 & - & - & - \\
\hline Tat $19-53 \mathrm{~m}$ & 0.05 & - & 500 & 1500 & 200 & 100 & 200 & 100 & 5000 & 4000 & 300 & - & - & - & - & - & 300 & - & - & - \\
\hline Tat $44-61$ & 0.25 & - & - & - & - & - & & - & - & 700 & - & - & - & - & 200 & 10000 & 400 & - & - & - \\
\hline
\end{tabular}

Rhesus macaques were immunised with unconjugated Tat peptides as described in Table 2. The reactivity of bleedings was evaluated by ELISA using the Tat protein and peptides tested as antigens for coating plates. IgG antibodies only were tested and the data described here correspond to the test of the bleeding collected 1 month after the sixth injection for the groups A, B and C, and the bleeding collected 1 month after the fourth injection for the groups D and E. The bleeds collected from each monkey before immunisation were used to determine the cut-off of positivity of the respective assays. The data are expressed as antibody titres corresponding to the reciprocal dilution giving an OD value equal to 0.2 . The sign $(-)$ stands for titres $<100$. As a control, the sera were tested with the measles peptide coated onto PVC Falcon plates at $0.05 \mu \mathrm{M}$ and onto Maxisorp ${ }^{\mathrm{TM}}$ plates at $0.1 \mu \mathrm{M}$, and they were negative (titres $<100$ ). 
the titre of antisera measured with immobilised Tat and the amount of soluble Tat required to inhibit $50 \%$ of the antibody reaction (IC50). When the Tat fragment 8-53 was coated on the plate and Tat protein used in the fluid phase (Fig. 4b), antibody binding to fragment 8-53 was strongly inhibited by soluble Tat in the case of sera 0299, 1092, 1096 and 1098 but not at all by antibodies from sera 0178 and 0201 . This result indicates that in addition to cross-reactive Tat antibodies, macaques 0178 and 0201 that received fragment 8-53 as immunogen also developed an antibody subset highly specific for fragment $8-53$ that did not cross-react with the parent protein Tat.

\subsection{Reactivity in ELISA of antibodies from HIV-infected macaques}

The serum from three rhesus macaques infected with the chimeric SHIV BX08 strain was tested in parallel with the whole Tat Bru protein and the six Tat peptides. The tests were negative except with peptide 44-61, which was recognised by the antibodies from three macaques PS1, PS2 and PS10 (data not shown).

\subsection{Antibodies to Tat peptides inhibit Tat-induced apoptosis}

To better characterise the properties of antibodies generated against Tat peptides, we next tested their ability to inhibit Tat-induced apoptosis. For this study we designed an assay in which Jurkat $\mathrm{T}$ cells incubated with anti-CD3 antibodies OKT3 (to initiate the induction of apoptosis) were allowed to react with Tat and different Tat fragments in the presence or not of antibodies to Tat peptides (Fig. 5a). Apoptosis was evaluated by FACS after labelling of cells with propidium iodide and annexin V (Fig. 5b). Using this test we first investigated directly the ability of six Tat fragments to induce apoptosis and found that all Tat peptides but peptide 1-20 activate apoptosis and are as efficient as the whole Tat protein (Fig. 5c). Next, we tested the ability of specific anti-Tat antibodies to inhibit apoptosis induced by the whole protein and Tat fragments. As shown in Fig. 5d with affinity-purified rabbit antibodies directed to peptide 44-61 (purified from the antiserum Lan), apoptosis induced by peptide 44-61 was clearly inhibited by increasing amounts of specific antibodies. Antisera raised to peptide 1-20 (Mac), 8-53 (Kaz), 19-53 (Bil), 19-53m (Lus) and 44-61 (Lan), but not antibodies from a control serum (Roc) directed to peptide 88-99 of histone H4, inhibited apoptosis induced by the whole protein Tat (Fig. 5e). Finally, we tested monkey antisera and found that several of them also inhibited apoptosis induced by the whole protein Tat (Fig. 5f). Thus the serum from macaques 0178, 0201, 0299, 1092, 1096 and 1098, which all react with the whole protein Tat in ELISA, but not the serum from the control macaque 1061, inhibited significantly apoptosis.

\section{Discussion}

HIV-1 Tat protein, which transactivates HIV-1 expression, exerts many effects on host immune functions. Because Tat protein is secreted by HIV-1 infected cells and can be rapidly taken-up by neighbouring cells in which it can generate numerous deleterious effects on non-infected cells or reactivate latent infection in infected cells, Tat represents an attracting target for the development of therapeutic strategies. The goal is to control viral infection by blocking the extracellular Tat, in particular during the uptake phase, by specific antibodies. The context is favourable since the immunogenic regions of Tat are relatively well conserved among all viral subtypes except $\mathrm{O}$ subtype. This approach associated to other strategies aimed to hamper virus entry might efficiently control virus replication and transmission and block disease onset and progression.

The first data obtained with whole Tat are encouraging and show that vaccination with recombinant Tat gives rise to the control of the acute phase of infection in nonhuman primates $[30,44]$. To avoid the possible deleterious effects of biologically active Tat, it has been proposed to use inactivated forms of the Tat protein $[25,30]$. An alternative approach could be the use of synthetic Tat peptides, which can be replaced in a further step by innocuous analogues of high stability for vaccination strategies. The question remains to identify which region(s) of Tat would be the most appropriate to raise antibodies able to react with extracellular Tat and to block its deleterious functions. To approach this question, we have immunised 12 rabbits and 16 monkeys with a series of Tat peptides and examined the immune response and the quality and specificity of the generated antibodies. We have compared the characteristics of these antibodies to those of antibodies induced after infection in patients and monkeys.

In good agreement with previous studies [19-21], at least two antigenic regions recognised by antibodies from HIV-infected individuals were identified in Tat (Table 2; Figs. 1 and 2). One epitope is located in the basic peptide 44-61 (GISYGRKKRRQRRRPPQG). A second epitope is present in fragment 8-53. Since peptide 1-20 was not recognised and since compared to fragment 8-53, fragment 19-53 was less well recognised, it could be concluded that this second epitope probably encompasses residues in the region surrounding the amino acids $18-25$. The results obtained with the fragment $19-53 \mathrm{~m}$ suggest further that this epitope might be contained in a larger region involving residues $30-35$, which are probably better accessible in the fragment containing $\mathrm{C} \rightarrow \mathrm{S}$ mutations in positions 27 , 31 and 37 that certainly exhibits different folding features compared to the wild type fragment containing the three cysteine residues. IgG antibodies reacting with peptides 1-61 and 44-61 were found significantly more frequently in FP patients while antibodies reacting with fragments $8-53$ and $19-53 \mathrm{~m}$ were present indiscriminately in FP and SP individuals (Fig. 2). These observations somewhat differ from previous results showing, for example, that antibodies 
(a)

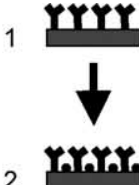

4

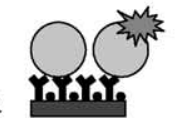

3

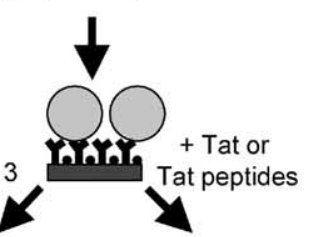

(b)

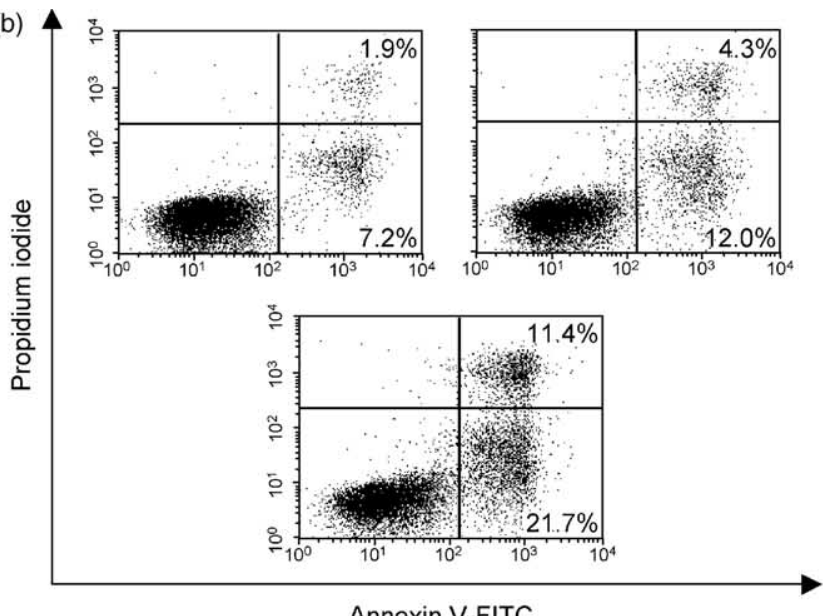

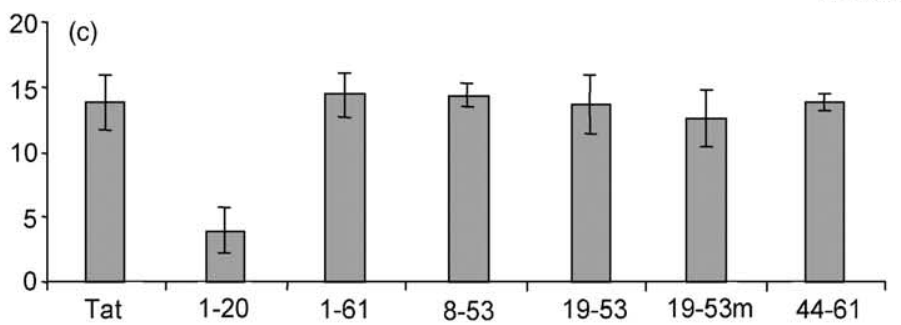

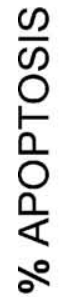

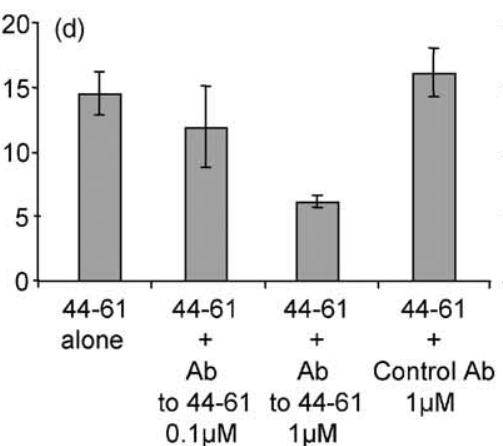

(e)

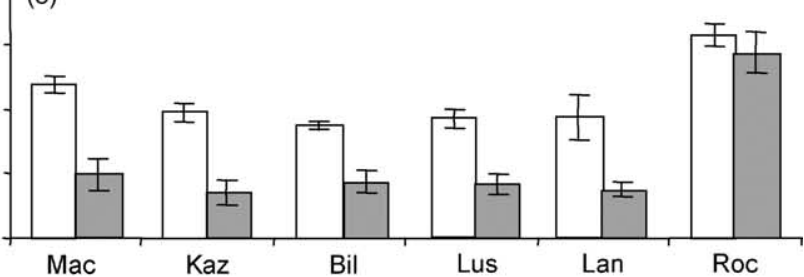

Tat $1 \mu \mathrm{M}+$ rabbit antisera to Tat peptides

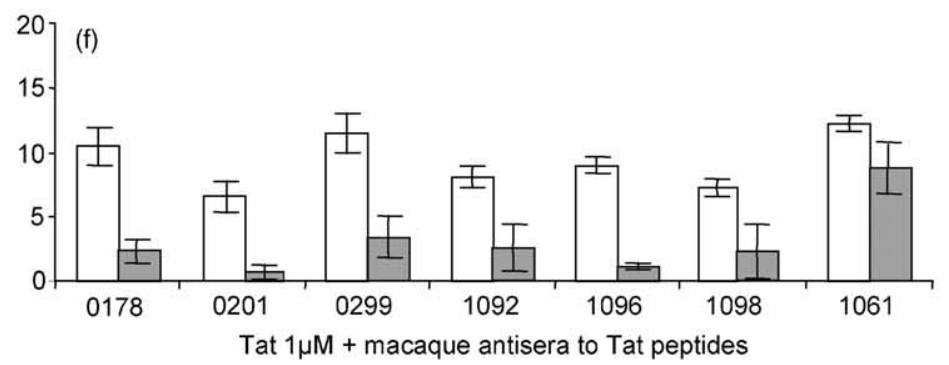

Fig. 5. Antibodies to Tat peptides inhibit Tat-induced apoptosis. (a) Principle of the test. The different steps of the induction of apoptosis of Jurkat cells are described from the top to the bottom, namely, the coating of the anti-CD3 antibody OKT3 (1); the blocking step with culture medium (2); the incubation of the Jurkat cells (3); with (bottom right) or without (bottom left) Tat protein or peptides (4, 5); a symbol represents the labelling intensity, which corresponds to apoptosis. (b) The panels represent the flow cytometry analysis of Jurkat cells stained with propidium iodide and annexin V. Jurkat cells cultured in culture medium only (top-left). Cells in the up-right and low-right quadrants are spontaneous apoptotic cells (9\% of the whole cell population). Increase of the percentage of apoptotic cells in Jurkat cells cultured in the presence of coated OKT3 antibody (16\% of the whole cell population) (top-right). Further increase of the percentage of apoptotic cells in Jurkat cells cultured in the presence of coated OKT3 and $1 \mu \mathrm{M}$ of Tat protein (33\% of the whole cell population) (bottom). (c) Effect of Tat and Tat peptides. The bars represent the difference between the specific apoptosis induced by OKT3 alone and the specific apoptosis induced by OKT3 in the presence of $1 \mu \mathrm{M}$ of the protein or peptides. Tests done in triplicate. (d) Affinity-purified rabbit antibodies $(\mathrm{Ab})$ to the 44-61 peptide from a serum pool from rabbits Lan and Cam specifically inhibit the apoptotic effect of peptide 44-61. The control antibodies were directed to peptide 147-156 of foot-and-mouth disease virus VP1 and were affinity-purified on protein G. The concentration of antibodies is indicated in the figure (test in duplicate). (e) Rabbit and (f) macaques antisera to Tat peptides ( $\boldsymbol{\square}$ ) inhibit the apoptotic effect of Tat. The reactivity of sera collected before immunisation of each animal is shown as control ( $\square$ ). The specificity of rabbit antisera is described in Table 4, the control antiserum Roc was directed to peptide 88-99 of histone H4. The specificity of macaque antisera is described in Tables 2 and 5 (tests done in duplicates). 
reacting with Tat peptides 6-14, 36-50 and 46-60 are more frequent in SP individuals with undetectable viral load [21]. These discrepancies may be due to the fine specificity of antibody tested and to their titre in the serum of infected patients.

Important differences were found after infection between human and monkey sera in terms of antibody specificity. Our data showed that IgG antibodies from infected macaques reacted with Tat peptide 44-61 only (not shown) while human sera reacted with several large and short fragments suggesting a very distinct antibody response probably related to the mode of infection and the level of viral load at the time of infection. It may also reflect a certain level of spreading of the antibody response between infection and the time, relatively short in macaques and much longer in infected patients, of blood sampling.

Sera from infected individuals and monkeys reacted strongly in ELISA with the whole Tat protein. A majority of antisera induced in rabbits and monkeys against the peptide $8-53$ alone or as cocktail or against the mixture of peptides 1-20, 1-61 and 44-61 reacted also with the cognate Tat protein (Tables 4 and 5; Fig. 4). However, none of the rabbits immunised with peptides 1-20 and 44-61 generated high titres of Tat cross-reacting antibodies. These results suggest that at least one epitope encompassed in the fragment 8-53 and 1-61 (not present in peptides 1-20 and 19-53) is important to generate a subset of antibodies cross-reacting in ELISA with the parent Tat protein. To this regard it is important to note that the monoclonal TA9 that recognises an epitope present in peptides 1-20, 1-61 and 8-53 gives the highest titres with the immobilised Tat protein (Fig. 3). Compared to the other monoclonal antibodies tested, TB12 specific for peptide 44-61 reacted relatively weakly with Tat (Fig. 3).

The functional activity of generated antibodies was tested with cells undergoing apoptosis. In the test designed for this study, apoptosis was induced by anti-CD3 antibodies and Tat or Tat fragments, and antibodies to Tat were tested for their ability to inhibit apoptosis. All Tat peptides except peptide 1-20 were able to activate apoptosis with the same efficiency as the whole Tat protein, and rabbit and macaques antibodies were able to inhibit this important function. We found no direct correlation between the titre of antibodies to Tat (measured in direct or competitive ELISA) and their capacity to block induced apoptosis.

In conclusion, our results support the notion that selected Tat peptides can effectively generate antibodies able to inhibit major functions of the extracellular Tat and may thus represent good candidates for therapeutic application. The correct choice of such peptides is delicate since slight sequence modifications seem to lead to major differences in their antigenic and immunological properties. It will be important in the future to delineate more precisely a peptide lead and to design novel analogues, for example, cyclic or pseudopeptide analogues with enhanced immunogenic activities and stability. Furthermore, Tat possesses many other deleterious extracellular properties and it remains to be tested whether antibodies to such Tat peptides can block some of them, for example, NK cell activation occurring upon contact with dendritic cells, the expression of CCR5 and CXCR4 co-receptors, or the effects on angiogenesis. Associated to other strategies, passive or active humoral immunity against Tat might then be important for controlling virus replication and blocking disease onset.

\section{Acknowledgements}

We are grateful to Dr. H. Walczak (Heidelberg, Germany) for the gift of Jurkat cells, Dr. J.-L. Guesdon (Institut Pasteur, Paris) for the anti-Tat monoclonal antibodies, and SEPPIC for the adjuvant Montanide ISA 720. Work in our laboratories was supported by grants from ANRS, the French National AIDS Research Agency (to S.M. and C.D.). O.C. was the recipient of a SIDACTION fellowship.

\section{References}

[1] Karn J. Tackling Tat. J Mol Biol 1999;293:235-54.

[2] Gatignol A, Jeang KT. Tat as a transcriptional activator and a potential therapeutic target for HIV-1. Adv Pharmacol 2000;48:209-27.

[3] Marcello A, Zoppe M, Giacca M. Multiple modes of transcriptional regulation by the HIV-1 Tat transactivator. IUBMB Life 2001;51:175-81.

[4] Liang C, Wainberg MA. The role of Tat in HIV-1 replication: an activator and/or a suppressor? AIDS Rev 2002;4:41-9.

[5] Westendorp MO, Frank R, Ochsenbauer C, Stricker K, Dhein J, Walczak H, et al. Sensitization of T cells to CD95-mediated apoptosis by HIV-1 Tat and gp120. Nature 1995;375:497-500.

[6] Frankel AD, Biancalana S, Hudson D. Activity of synthetic peptides from the Tat protein of human immunodeficiency virus type 1. Proc Natl Acad Sci USA 1989;86:7397-401.

[7] Wrenger S, Hoffmann T, Faust J, Mrestani-Klaus C, Brandt W, Neubert K, et al. The N-terminal structure of HIV-1 Tat is required for suppression of CD26-dependent $\mathrm{T}$ cell growth. J Biol Chem 1997;272:30283-8

[8] Albini A, Ferrini S, Benelli R, Sforzini S, Giunciuglio D, Aluigi MG, et al. HIV-1 Tat protein mimicry of chemokines. Proc Natl Acad Sci USA 1998;95:13153-8.

[9] Boykins RA, Mahieux R, Shankavaram UT, Gho YS, Lee SF, Hewlett IK, et al. A short polypeptide domain of HIV-1-Tat protein mediates pathogenesis. J Immunol 1999;163:15-20.

[10] Wrenger S, Reinhold D, Faust J, Mrestani-Klaus C, Brandt W, Fengler A, et al. Effects of nonapeptides derived from the N-terminal structure of human immunodeficiency virus-1 (HIV-1) Tat on suppression of CD26-dependent T cell growth. Adv Exp Med Biol 2000;477:161-5.

[11] Betti M, Voltan R, Marchisio M, Mantovani I, Boarini C, Nappi F, et al. Characterization of HIV-1 Tat proteins mutated in the transactivation domain for prophylactic and therapeutic application. Vaccine 2001;19:3408-19.

[12] Poggi A, Carosio R, Spaggiari GM, Fortis C, Tambussi G, Dell'Antonio G, et al. NK cell activation by dendritic cells is dependent on LFA-1-mediated induction of calcium-calmodulin kinase II: inhibition by HIV-1 Tat C-terminal domain. J Immunol 2002;168:95-101.

[13] Benelli R, Barbero A, Ferrini S, Scapini P, Cassatella M, Bussolino $\mathrm{F}$, et al. Human immunodeficiency virus transactivator protein 
(Tat) stimulates chemotaxis, calcium mobilization, and activation of human polymorphonuclear leukocytes: implications for Tat-mediated pathogenesis. J Infect Dis 2000;182:1643-51.

[14] Rossi C, Balboni PG, Betti M, Marconi PC, Bozzini R, Grossi MP, et al. Inhibition of HIV-1 replication by a Tat transdominant negative mutant in human peripheral blood lymphocytes from healthy donors and HIV-1-infected patients. Gene Ther 1997;4:1261-9.

[15] Kiernan RE, Vanhulle C, Schiltz L, Adam E, Xiao H, Maudoux F, et al. HIV-1 tat transcriptional activity is regulated by acetylation. EMBO J 1999;18:6106-18.

[16] Ott M, Schnolzer M, Garnica J, Fischle W, Emiliani S, Rackwitz HR, et al. Acetylation of the HIV-1 Tat protein by p300 is important for its transcriptional activity. Curr Biol 1999;9:1489-92.

[17] Krone WJ, Debouck C, Epstein LG, Heutink P, Meloen R, Goudsmit J. Natural antibodies to HIV-tat epitopes and expression of HIV-1 genes in vivo. J Med Virol 1988;26:261-70.

[18] McPhee DA, Kemp BE, Cumming S, Stapleton D, Gust ID, Doherty RR. Recognition of envelope and tat protein synthetic peptide analogs by HIV positive sera or plasma. FEBS Lett 1988;233:393-6.

[19] Tähtinen M, Ranki A, Valle SL, Ovod V, Krohn K. B-cell epitopes in HIV-1 Tat and Rev proteins colocalize with T-cell epitopes and with functional domains. Biomed Pharmacother 1997;51:480-7.

[20] Demirhan I, Chandra A, Hasselmayer O, Biberfeld P, Chandra P. Detection of distinct patterns of anti-tat antibodies in HIV-infected individuals with or without Kaposi's sarcoma. J Acquir Immune Defic Syndr 1999;22:364-8.

[21] Re MC, Vignoli M, Furlini G, Gibellini D, Colangeli V, Vitone $\mathrm{F}$, et al. Antibodies against full-length Tat protein and some low-molecular-weight Tat-peptides correlate with low or undetectable viral load in HIV-1 seropositive patients. J Clin Virol 2001;21:81-9.

[22] Rodman TC, Pruslin FH, To SE, Winston R. Human immunodeficiency virus (HIV) Tat-reactive antibodies present in normal HIV-negative sera and depleted in HIV-positive sera. Identification of the epitope. J Exp Med 1992;175:1247-53.

[23] Rodman TC, To SE, Hashish H, Manchester K. Epitopes for natural antibodies of human immunodeficiency virus (HIV)-negative (normal) and HIV-positive sera are coincident with two key functional sequences of HIV Tat protein. Proc Natl Acad Sci USA 1993;90:7719-23.

[24] Re MC, Furlini G, Vignoli M, Ramazzotti E, Zauli G, La Placa M. Antibody against human immunodeficiency virus type 1 (HIV-1) Tat protein may have influenced the progression of AIDS in HIV-1-infected hemophiliac patients. Clin Diagn Lab Immunol 1996;3:230-2.

[25] Zagury JF, Sill A, Blattner W, Lachgar A, Le Buanec H, Richardson $\mathrm{M}$, et al. Antibodies to the HIV-1 Tat protein correlated with nonprogression to AIDS: a rationale for the use of Tat toxoid as an HIV-1 vaccine. J Hum Virol 1998;1:282-92.

[26] Rodman TC, Sullivan JJ, Bai X, Winston R. The human uniqueness of HIV: innate immunity and the viral Tat protein. Hum Immunol 1999;60:631-9.

[27] Goldstein G, Manson K, Tribbick G, Smith R. Minimization of chronic plasma viremia in rhesus macaques immunized with synthetic HIV-1 Tat peptides and infected with a chimeric simian/human immunodeficiency virus (SHIV33). Vaccine 2000;18:2789-95.

[28] Cafaro A, Caputo A, Fracasso C, Maggiorella MT, Goletti D, Baroncelli S, et al. Control of SHIV-89.6P-infection of cynomolgus monkeys by HIV-1 Tat protein vaccine. Nat Med 1999;5:643-50.

[29] Cafaro A, Titti F, Fracasso C, Maggiorella MT, Baroncelli S, Caputo A, et al. Vaccination with DNA containing tat coding sequences and unmethylated $\mathrm{CpG}$ motifs protects cynomolgus monkeys upon infection with simian/human immunodeficiency virus (SHIV89.6P). Vaccine 2001;19:2862-77.

[30] Pauza CD, Trivedi P, Wallace M, Ruckwardt TJ, Le Buanec H, Lu $\mathrm{W}$, et al. Vaccination with tat toxoid attenuates disease in simian/ HIV-challenged macaques. Proc Natl Acad Sci USA 2000;97: 3515-9.

[31] Li-Weber M, Laur O, Dern K PH. T cell activation-induced and HIV tat-enhanced CD95 (APO-1/Fas) ligand transcription involves NF-kappaB. Eur J Immunol 2000;30:661-70.

[32] Péloponèse JM, Collette Y, Grégoire C, Bailly C, Campèse D, Meurs $\mathrm{EF}$, et al. Full peptide synthesis, purification, and characterization of six Tat variants. Differences observed between HIV-1 isolates from Africa and other continents. J Biol Chem 1999;274:11473-8.

[33] Cornille F, Wecker K, Loffet A, Genet R, Roques B. Efficient solid-phase synthesis of $\mathrm{Vpr}$ from HIV-1 using low quantities of uniformly 13C-, 15N-labeled amino acids for NMR structural studies. J Pept Res 1999;54:427-35.

[34] Neimark J, Briand JP. Development of a fully automated multichannel peptide synthesizer with integrated TFA cleavage capability. Pept Res 1993;6:219-28.

[35] Phan Chan Du A, Limal D, Semetey V, Dali H, Jolivet M, Desgranges $\mathrm{C}$, et al. Structural and immunological characterisation of heteroclitic peptide analogues corresponding to the 600-612 region of the HIV envelope gp41 glycoprotein. J Mol Biol 2002;323:503-21.

[36] Partidos CD, Salani BF, Pizza M, Rappuoli R. Heat-labile enterotoxin of Escherichia coli and its site-directed mutant LTK63 enhance the proliferative and cytotoxic T-cell responses to intranasally co-immunized synthetic peptides. Immunol Lett 1999;67:209-16.

[37] Hendel H, Cho YY, Gauthier N, Rappaport J, Schachter F, Zagury JF. Contribution of cohort studies in understanding HIV pathogenesis: introduction of the GRIV cohort and preliminary results. Biomed Pharmacother 1996;50:480-7.

[38] Rappaport J, Cho YY, Hendel H, Schwartz EJ, Schachter F, Zagury JF. 32 bp CCR-5 gene deletion and resistance to fast progression in HIV-1 infected heterozygotes. Lancet 1997;349:922-3.

[39] Verrier B, Le Grand R, Ataman-Onal Y, Terrat C, Guillon C, Durand PY, et al. Evaluation in Rhesus macaques of Tat and Rev-targeted immunization as a preventive vaccine against mucosal challenge with SHIV-BX08. DNA Cell Biol 2002;21:653-8.

[40] Beignon AS, Briand JP, Muller S, Partidos CD. Immunization onto bare skin with heat-labile enterotoxin of Escherichia coli enhances immune responses to coadministered protein and peptide antigens and protects mice against lethal toxin challenge. Immunology 2001;102:344-51.

[41] Gnann Jr JW, Schwimmbeck PL, Nelson JA, Truax AB, Oldstone MBA. Diagnosis of AIDS by using a 12-amino acid peptide representing an immunodominant epitope of the human immunodeficiency virus. J Infect Dis 1987;156:261-7.

[42] Smith RS, Naso RB, Rosen J, Whalley A, Hom YL, Hoey K, et al. Antibody to a synthetic oligopeptide in subjects at risk for human immunodeficiency virus infection. J Clin Microbiol 1987;25: 1498-504.

[43] Närvänen A, Korkolainen M, Suni J, Korpela J, Kontio S, Partanen $\mathrm{P}$, et al. Synthetic env gp41 peptide as a sensitive and specific diagnostic reagent in different stages of human immunodeficiency virus type 1 infection. J Med Virol 1988;26:111-8.

[44] Cafaro A, Caputo A, Maggiorella MT, Baroncelli S, Fracasso C, Pace M, et al. SHIV89.6P pathogenicity in cynomolgus monkeys and control of viral replication and disease onset by human immunodeficiency virus type 1 Tat vaccine. J Med Primatol 2000;29:193-208. 